\title{
Screening cabbage rhizosphere as a habitat for isolation of phosphate-solubilizing bacteria
}

\author{
Hossein Motamedi ${ }^{1,2 *}$, Sholeh Aalivand ${ }^{1}$, Hossein Najafzadeh Varzi', \\ Mohammad Mohammadi ${ }^{1}$
}

\author{
${ }^{1}$ Department of Biology, Faculty of Science, Shahid Chamran University of Ahvaz, Ahvaz, Iran \\ ${ }^{2}$ Biotechnology and Biological Science Research Center, Shahid Chamran University of Ahvaz, Ahvaz, Iran \\ ${ }^{3}$ Department of Pharmacology, Faculty of Veterinary Medicine, Shahid Chamran University of Ahvaz, Ahvaz, Iran \\ *Corresponding author, E-mail: motamedih@scu.ac.ir, hhmotamedi@yahoo.com
}

\begin{abstract}
Phosphorus plays a major role in plant growth, but due to insoluble complex formation in soil, it is mainly unavailable for plants. Phosphate solubilizing bacteria dissolve phosphate and hence are regarded as biofertilizer. These bacteria are present in different habitats and screening of such habitats can introduce potent phosphate solubilizing bacteria as biologic fertilizer. The aim was finding such isolates from cabbage rhizosphere. Soil samples were enriched and screened using Pikovskaya's agar. Isolates were identified by phenotypic and genotypic methods. Their biological activities were also investigated. Four of these isolates had highest phosphate solubilization index (1.3 to 4.7 ) and phosphate solubilization efficiency (33.3 to 366.6). Inorganic phosphate solubilizing ability of these strains was 6.74 to $89.1 \mathrm{mg} \mathrm{L}{ }^{-1}$. The predominant organic acid found was oxalic acid for RK33 isolate. All phosphate solubilizing strains were able to fix nitrogen, while only RK24 and RK33 produced phytase. These isolates were Aeromonas sp., Proteus sp., Proteus mirabilis and Raoultella terrigena. Finally, it can be concluded that cabbage rhizosphere is a potent habitat for finding phosphate solublizing bacteria, which can be applied as biofertilizer, thus avoiding undesirable side effects of chemical fertilizers.
\end{abstract}

Key words: biofertilizer, cabbage, phosphorus, phosphate-solublizing bacteria, rhizosphere.

Abbreviations: PSB, phosphate solubilizing bacteria; SE. solubilization efficiency; SI, solubilization index.

\section{Introduction}

Phosphorus is one of the major essential macronutrients limiting plant growth because of its low bioavailability in soils (Tao et al. 2008). Many biochemical and physiological activities in plants, such as photosynthesis, root system development, cell division, nitrogen fixation in legumes, resistance to plant pathogens, plant health and utilization of carbohydrate are dependent to the vital role of this element (Khan et al. 2009; Guinazuet al. 2010; Karpagam, Nagalakshmi 2014).

Phosphorus can be found in nature as organic and mineral forms (Kundu et al. 2009). The concentration of soluble $\mathrm{P}$ in soil is very low, varying from $0.001 \mathrm{mg} \mathrm{L}^{-1}$ in very poor soils to $1 \mathrm{mg} \mathrm{L} \mathrm{L}^{-1}$ in heavily fertilized soils. The forms of $\mathrm{P}$ that are taken up by plants from soil solution are phosphate anions (mainly $\mathrm{H}_{2} \mathrm{PO}_{4}^{-}$and $\mathrm{HPO}_{4}{ }^{2-}$; Antoun 2012). Usage of phosphatic fertilizers in soil results in a significant amount of them (more than $70 \%$ ) being rapidly converted into less available forms, because prior to their absorption by plant roots, they form insoluble complexes with $\mathrm{Fe}$ or $\mathrm{Al}$ in acid soils and $\mathrm{Ca}$ or $\mathrm{Mg}$ in calcareous soils (Hui et al. 2011). As a result, plants can only take up 10 to $15 \%$ of the soluble $\mathrm{P}$ added as fertilizers during a year of application (Antoun 2012). Soil salinity, accumulation of $\mathrm{P}$, large losses of $\mathrm{N}$, water eutrophication, accumulation of heavy metals in soils and plant system and low recovery by crops are consequences of excess and long-term application of phosphate fertilizers, which can cause environmental pollution (Tao et al. 2008; Savci 2012).

One alternative is to increase $\mathrm{P}$ availability through biological approaches (Alam et al. 2002). Several bacterial species are known to be involved in mineralization and solubilization of organic and inorganic phosphorus in soil, respectively (Panhwar et al. 2012; Karpagam, Nagalakshmi 2014). Rhizospheric bacteria with phosphate solubilizing activity have been reported (Mittal et al. 2008). The main strains with this capability belong to the Pseudomonas, Mycobacterium, Micrococcus, Bacillus, Achromobacter, Erwinia, Agrobacterium, Burkholderia, Flavobacterium, Rhizobium, Mesorhizobium, Arthrobacter, Alcaligenes, Serratia, Enterobacter, Acinetobacter and Sinorhizobium genera (Fernandez et al. 2007; Guinazu et al. 2010). Various mechanisms, such as organic and inorganic acids production and secretion and phosphatase enzyme secretion, cause dissolution of mineral phosphates and hydrolysis of organic phosphates in soil (Yadav, Verma 2012). Some organic acids produced by rhizospheric phosphate solubilizing 
bacteria (PSB) are citric, lactic, propionic, glycolic, oxalic, succinic, fumaric and tartaric acids (Ivanova et al. 2006). These organic acids chelate the cations ( $\mathrm{Al}, \mathrm{Fe}, \mathrm{Ca}$ ) bound to mineral phosphate and transform them to soluble forms through their hydroxyl and carboxyl groups, making it available for plants (Panhwar et al. 2012).

In recent years, use of phosphate solubilizing bacteria as biofertilizers for agricultural improvement has attracted the attention of researchers (Vessy 2003). Biological fertilizers containing phosphate solubilizing bacteria could help to increase the availability of soil phosphorus, increase yield of plant, minimization of harmful effects of phosphate fertilizers, reduce environmental pollution and promote sustainable agricultural development (Chen et al. 2006). Research on PSB can be a new approach to improve the absorption of phosphorus in agricultural soil. The aim of this study was to screening and characterization of potential phosphate solubilizing bacteria from cabbage rhizosphere, for use as biofertilizer.

\section{Materials and methods}

\section{Sample collection}

Rhizospheric soil samples were collected from three different cabbage fields located in Shushtar $\left(32.0456^{\circ} \mathrm{N}\right.$, $48.8567^{\circ} \mathrm{E}$ ), Iran. In each field three different locations were randomly selected and $100 \mathrm{~g}$ soil samples were harvested from surface to $30 \mathrm{~cm}$ depth of soil. Samples were immediately transferred to the microbiology laboratory and stored at $4{ }^{\circ} \mathrm{C}$ temperature before analysis.

\section{Isolation of phosphate-solubilizing bacteria}

Ten grams of soil from each sample was homogenized in a $250 \mathrm{~mL}$ Erlenmeyer flask containing $90 \mathrm{~mL}$ sterilized distilled water through continuous rotation at $180 \mathrm{rpm}$ for $30 \mathrm{~min}$ (Hui et al., 2011). A tenth $\mathrm{ml}$ of supernatant was cultured on Pikovskaya's agar medium (Glucose 10 $\mathrm{g}$; tricalcium phosphate $5 \mathrm{~g}$; ammonium sulphate $0.5 \mathrm{~g}$; sodium chloride $0.2 \mathrm{~g}$; potassium chloride $0.2 \mathrm{~g}$; magnesium sulphate $0.1 \mathrm{~g}$; yeast extract $0.5 \mathrm{~g}$; manganese sulphate trace; ferrous sulphate trace and agar $15 \mathrm{~g}$ per $1 \mathrm{~L}$ of distilled water; $\mathrm{pH} 7.0 \pm 0.2$ ). The medium was supplemented with cycloheximide $\left(50 \mu \mathrm{g} \mathrm{mL}^{-1}\right)$ to inhibit the growth of fungi. The plates were incubated at $28 \pm 2{ }^{\circ} \mathrm{C}$ in an incubator (Fan Azma Gostar, Iran) for 24 to $48 \mathrm{~h}$. A clear zone around colonies were used as a clue for the presence of phosphate solubilizing bacteria. Different PSB isolates were selected on the basis of colony morphology. These isolates were purified on fresh Pikovskaya's agar medium and stored on nutrient agar at $4{ }^{\circ} \mathrm{C}$ (Ramani 2011).

\section{Determination of phosphate solubilization efficiency and solubilization index}

The Pikovskaya's medium was modified by addition of 4.0 $\mathrm{mL}$ of $0.16 \%$ bromophenol blue solution (in ethanol) before sterilization and was used for determination of phosphate solubilization activity on the basis of formation of a clear zone around colonies. Phosphate solubilizing ability of each isolate was assayed by spotting $10 \mu \mathrm{L}$ of bacterial inoculants at the center of Modified Pikovskaya's agar. Growth and solubilization diameter were measured after incubation at $30^{\circ} \mathrm{C}$ for seven days. Solubilization efficiency (SE) and solubilization index (SI) were calculated using the following formulas (Qureshi et al. 2012):

PSE $(\%)=$ halo zone diameter $/$ colony diameter $\times 100$;

$\mathrm{SI}=($ colony diameter + halo $z$ one diameter $) /$ colony diameter.

\section{Determination of phosphate solubilizing activity}

The phosphate solubilizing activity of PSB strains was quantitatively evaluated by using $25 \mathrm{~mL}$ of Pikovskaya's broth medium and $0.25 \mathrm{~mL}$ of bacterial inoculant

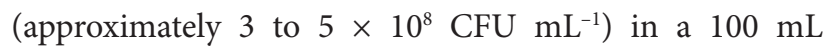
Erlenmeyer's flask. Uninoculated medium served as a control and all flasks were incubated on a shaker (GfL 3021, Germany) for 5 days at $150 \mathrm{rpm}$ and $30^{\circ} \mathrm{C}$ (Hui et al. 2011). Then the cultures were centrifuged at $11000 \mathrm{rpm}$ for 10 min and the amount of released soluble phosphate in the supernatant was determined by the ascorbic acid method. In quantitative assay, the reaction mixture contained $1 \mathrm{~mL}$ of supernatant plus $9 \mathrm{~mL}$ of distilled water and $2.5 \mathrm{~mL}$ color reagent. The color reagent was freshly prepared by mixing $50 \mathrm{~mL}$ of antimonyl potassium tartrate solution $(0.036 \mathrm{~g}$ antimony potassium tartrate $\left[\mathrm{K}(\mathrm{SbO}) \mathrm{C}_{4} \mathrm{H}_{4} \mathrm{O}_{6} \times 1 / 2 \mathrm{H}_{2} \mathrm{O}\right]$ in $125 \mathrm{~mL}$ of $5 \mathrm{~N} \mathrm{H}_{2} \mathrm{SO}_{4}$ ) with $12.5 \mathrm{~mL}$ ammonium molybdate solution (1.5 g ammonium molybdate $\left[\left(\mathrm{NH}_{4}\right)_{6} \mathrm{Mo}_{7} \times\right.$ $4 \mathrm{H}_{2} \mathrm{O}$ ] plus $31.5 \mathrm{~mL}$ distilled water). Both solutions were mixed and stirred while slowly adding $0.264 \mathrm{~g}$ ascorbic acid, and volume was adjusted to $100 \mathrm{~mL}$. The optical density of developed blue color after $15 \mathrm{~min}$ was measured at 880 $\mathrm{nm}$ by a spectrophotometer (Optimize, Germany) and the concentration of available $\mathrm{P}\left(\mathrm{mg} \mathrm{kg}^{-1}\right)$ was calculated (Watanabe, Olsen 1965; Alam et al. 2002). The change in $\mathrm{pH}$ was measured (AZ, China) in supernatant after 5 days of incubation.

\section{Determination of organic acid production}

PSB strains were cultured in Pikovskaya's broth medium and incubated on a shaker at $150 \mathrm{rpm}$ for 5 days at 30 ${ }^{\circ} \mathrm{C}$. Then cultures were centrifuged (11000 rpm, $10 \mathrm{~min}$ ) and supernatant of each culture was monitored for oxalic acid, citric acid, malic acid and tartaric acid by thin-layer chromatography. Ten $\mu \mathrm{L}$ of samples were injected in the bottom of silica gel plates and developed with methanolammonium hydroxide (1:4) as the mobile phase. The plates were dried and then covered with $0.3 \%$ bromocresol green in solvent (water-methanol 4:1, with 8 drops of $30 \% \mathrm{NaOH}$ ). Presence of organic acids in samples was confirmed through visualizing the yellow spots on a green background. The detection limit of the method was $10 \mu \mathrm{g}$ $\mathrm{mL}^{-1}$ for all analyzed acids. 


\section{Nitrogen fixation assay}

Nitrogen fixation ability of isolates were examined using Dobereiner meduim containing bromothymol blue as an indicator. Each isolate was inoculated on this medium and incubated at $37^{\circ} \mathrm{C}$ for 24 to $48 \mathrm{~h}$. Yellow color change was regarded as qualitative evidence for atmospheric nitrogen fixation (Dobereiner 1972; Sgroy 2009).

\section{Phytase production assay}

Four PSB isolates were inoculated into the phytase screening medium $(1.5 \%$ glucose, $0.1 \%$ sodium phytate, $0.2 \% \mathrm{NH}_{4} \mathrm{NO}_{3}, 0.05 \% \mathrm{KCl}, 0.05 \% \mathrm{MgSO}_{4} \times 7 \mathrm{H}_{2} \mathrm{O}, 0.03 \%$ $\mathrm{MnSO}_{4}, 0.03 \% \mathrm{FeSO}_{4} \times 7 \mathrm{H}_{2} \mathrm{O}$ and $2 \%$ agar, $\mathrm{pH} 7.5$ ) and incubated at $30^{\circ} \mathrm{C}$ and $150 \mathrm{rpm}$ for three days. The supernatant ( $15 \mathrm{~min}$ at $6000 \mathrm{rpm}$ ) was subjected to phytase activity assay (Mittal et al. 2011). In qualitative enzyme assay, the reaction mixture contained $2 \mathrm{~mL}$ of supernatant plus $4 \mathrm{~mL}$ of substrate solution $(0.84 \%$ solution of sodium phytate in buffer solution, $\mathrm{pH}$ 5.5). The buffer solution was prepared by dissolving $0.18 \mathrm{~g}$ acetic acid, $3 \mathrm{~g}$ sodium acetate $\times 3 \mathrm{H}_{2} \mathrm{O}, 0.15 \mathrm{~g} \mathrm{CaCl}_{2} \times 2 \mathrm{H}_{2} \mathrm{O}$ in $100 \mathrm{~mL}$ distilled water with adjustment of $\mathrm{pH}$ at 5.5 with pure acetic acid. The reaction was conducted at $37^{\circ} \mathrm{C}$ for $65 \mathrm{~min}$ and then stopped by $4 \mathrm{~mL}$ of freshly prepared color reagent. The color reagent was prepared by mixing $25 \mathrm{~mL}$ of ammonium molybdate solution $\left(10 \mathrm{~g}\right.$ ammonium molybdate $\times 4 \mathrm{H}_{2} \mathrm{O}$ and $1 \mathrm{~mL} \mathrm{NH}_{3}$ (25\%) in $100 \mathrm{~mL}$ distilled water) with $25 \mathrm{~mL}$ ammonium vanadate solution $(0.235 \mathrm{~g}$ ammonium vanadate, $40 \mathrm{~mL}$ distilled water at $60{ }^{\circ} \mathrm{C}$, with slow addition of $2 \mathrm{~mL}$ of nitric acid before dilution to $100 \mathrm{~mL}$ ) and stirring while slowly adding $16.5 \mathrm{~mL}$ nitric acid (65\%). Then the mixture cooled to room temperature and adjusted to $100 \mathrm{~mL}$. The color change following phytase activity was measured at 415 $\mathrm{nm}$. In blank reaction, the color reagent was added prior to the enzyme sample. One unit of enzyme was defined as the amount of enzyme that can release $1 \mu \mathrm{mol}$ of inorganic phosphate in 1 min (Popanich et al. 2003). A standard graph was plotted using potassium dihydrogen phosphate with working concentration ranging from 0 to $600 \mu \mathrm{M}$.

\section{Identification of isolates}

The phosphate-solubilizing bacteria were identified both by conventional biochemical tests described in Bergey's Manual of Systematic Bacteriology and also by 16S rRNA sequencing as follows. Genomic DNA was extracted and purified using a DNA extraction kit (Cinna Gen, Iran) and the 16S rRNA sequence was amplified using FD1 (5'-CCGAATTCGTCGACAACAGAGTTTGATCCTGGCTCAG-3') and RP1 (5'-CCCGGGATCCAAGCTTACGGTTACCTTGTTACGACTT-3') primer (Weisburg et al. 1991). The reaction was performed in $25 \mu \mathrm{L}$ PCR reaction mixture $(0.2$ $\mu \mathrm{M}$ of each primer, $0.2 \mathrm{mM}$ dNTPs, $3 \mathrm{mM} \mathrm{MgCl}_{2}, 2.5 \mu \mathrm{L}$ PCR buffer, $1 \mathrm{U}$ Taq DNA polymerase and $2 \mu \mathrm{L}$ of template DNA in a thermal cycler (Bio-Radicycler, USA) with the following program: initial denaturation at $\left(94^{\circ} \mathrm{C}, 5 \mathrm{~min}\right)$,
30 cycles of denaturation $\left(94^{\circ} \mathrm{C}, 60 \mathrm{~s}\right)$, annealing $\left(58.1^{\circ} \mathrm{C}\right.$, $40 \mathrm{~s})$ and extension $\left(72{ }^{\circ} \mathrm{C}, 150 \mathrm{~s}\right)$ and a final extension at $72{ }^{\circ} \mathrm{C}$ for $10 \mathrm{~min}$ (Weisburg et al. 1991). The amplification was confirmed in agarose gel electrophoresis (1\% agarose, $2 \mu \mathrm{L}$ safe stain) and sequenced (Macrogen, Korea). The obtained sequences were edited by Bioedit (version 7.0.4.1) and analyzed by the BLAST algorithm of NCBI. The phylogenetic tree was constructed by the neighbor-joining method using the MEGA version 4 through comparison with other sequences in GenBank.

\section{Optimization of growth condition}

Effect of $\mathrm{pH}(5.5,7,8.5)$ and temperature $(25,30,35,40$ $\left.{ }^{\circ} \mathrm{C}\right)$ on growth condition of the RK33 strain were examined. Growth curve of this isolate was obtained in different $\mathrm{pH}$ and temperatures as triplicates. Erlenmeyer flasks (100 $\mathrm{mL}$ ) containing $40 \mathrm{~mL}$ of the nutrient broth medium were inoculated with a $1 \%(\mathrm{v} / \mathrm{v})$ inoculum. Non-inoculated medium served as a control. The flasks were incubated ( 150 $\mathrm{rpm}, 60 \mathrm{~h})$ at various temperatures $\left(25,30,35,40^{\circ} \mathrm{C}\right)$. The optical density of the bacterial culture was measured at $580 \mathrm{~nm}$ every $2 \mathrm{~h}$ (Bio-Rad, USA). After selection of the best growth temperature, this isolate was cultured at the different $\mathrm{pH}$ values, i.e, 5.5, 7 and 8.5.

\section{Optimization of phosphate solubilizing condition}

Effect of various parameters, including temperature, $\mathrm{pH}$, various nitrogen sources and various carbon sources on phosphate solubilizing activity was examined. All experiments were performed as triplicates. The Pikovskaya's broth medium was inoculated with inoculum $(1 \%, \mathrm{v} / \mathrm{v})$ and incubated at $150 \mathrm{rpm}$ for 5 days at various temperatures (25, $30,35,40^{\circ} \mathrm{C}$ ). Non-inoculated medium served as a control. Phosphate solubilization activity was assessed by ascorbic acid method. Then the $\mathrm{pH}$ of Pikovskaya's broth medium was adjusted to $5.5,7,8.5$ using $\mathrm{NaOH}(4 \mathrm{~N})$ or $\mathrm{HCl}(1 \mathrm{~N})$ and inoculated with RK33 isolate. Phosphate solubilization activity was evaluated by ascorbic acid method following incubation at $150 \mathrm{rpm}$ for 5 days and the optimum temperature obtained from the previous step.

For finding the effect of various carbon sources on phosphate solubilizing ability of RK33, different carbon sources including glucose, fructose and sucrose were used in Pikovskaya's broth medium. Temperature and $\mathrm{pH}$ were selected based on the obtained results; the isolate was inoculated and incubated at $150 \mathrm{rpm}$ for 5 days. Phosphate solubilizing activity was studied as previously mentioned. Similarly, the effect on nitrogen source, including $\left(\mathrm{NH}_{4}\right)_{2} \mathrm{SO}_{4}$-yeast extract, urea and $\mathrm{NaNO}_{3}$ was investigated. Finally, the effect of incubation period on phosphate solubilizing activity was surveyed by incubation of the inoculated optimized culture medium at $150 \mathrm{rpm}$ for 3, 5 and 7 days and the activity was measured by ascorbic acid method. 
Table 1. Phosphate solubilizing efficiency and solubilizing Index of isolates at 7th day of incubation)

\begin{tabular}{|lcccc} 
Isolates & Colony diameter $(\mathbf{m m})$ & Halozone diameter $(\mathbf{m m})$ & Solubilization index & \multicolumn{2}{c}{ Solubilization efficiency } \\
\hline RK11 & 8 & 12 & 1.50 & 50.0 \\
RK12 & 6 & 8 & 1.33 & 33.3 \\
RK13 & 4 & 6 & 1.50 & 50.0 \\
\hline RK14 & 7 & 11 & 1.57 & 57.1 \\
RK15 & 7 & 13 & 1.85 & 85.7 \\
\hline RK21 & 4 & 8 & 2.00 & 100.0 \\
RK23 & 4 & 9 & 2.25 & 125.0 \\
\hline RK24 & 3 & 14 & 4.66 & 366.6 \\
RK25 & 6 & 12 & 2.00 & 100.0 \\
RK26 & 9 & 13 & 1.40 & 44.4 \\
RK31 & 6 & 11 & 1.83 & 83.3 \\
RK32 & 6 & 11 & 1.83 & 83.3 \\
RK33 & 4 & 12 & 3.00 & 200.0 \\
\hline
\end{tabular}

\section{Results}

\section{Isolation and screening of phosphate solubilizing bacteria}

The soil samples from cabbage rhizosphere were screened for the presence of phosphate solubilizing bacteria on Pikovskaya's agar medium. As a result, 14 phosphate solubilizing strains were identified based on clear zone formation around colonies on PVK medium. The results of phosphate solubilizing efficiency (PSE) and phosphate solubilizing index (SI) of these isolates at $7^{\text {th }}$ day are presented in Table 1. Among these isolates, four isolates had highest SI, ranging from 1.3 to 4.7 and PSE ranged from 33.3 to 366.6 which were selected for further studies. Among these four potent isolates, the strain RK24 had higher phosphate solubilizing efficiency and index (Table 1). Modified Pikovskaya's agar containing bromophenol blue was used, as using this method a yellow color change can be obviously found as a result of acid production, making detection of a halo zone easier.

Phosphate solubilizing activity of the strains RK33, RK24, RK21 and RK25 were assayed in broth culture. The results demonstrated that the amounts of soluble $\mathrm{P}$ in the supernatants were in the range of 6.74 to $89.1 \mathrm{mg} \mathrm{L}^{-1}$ after five days of incubation (Table 2). In this experiment, RK33 released the highest amount of soluble phosphate.
This isolate was selected for further studies. Increase in the amount of soluble phosphate with decrease in the final $\mathrm{pH}$ of broth media was observed; this decrease in the $\mathrm{pH}$ of the culture was associated with the production of organic acids due to phosphate solubilizing activity. Organic acid was not detected in all cultures, perhaps due to the limitation of the methodology we used. The predominant organic acid found was oxalic acid in the supernatant of RK33. Among four strains, only RK24 and RK33 strains were found positive for phytase production. All PSB strains were able to fix nitrogen (Table 2).

\section{Identification of phosphate solubilizing bacteria}

Phenotypic identification showed RK21, RK24, RK25 and RK33 strains as Aeromonas sp., Proteus sp., Proteus mirabilis and Raoultella terrigenia, respectively. 16S rRNA sequencing of the RK33 strain showed $98 \%$ homology with Raoultella terrigenia. Fig. 1 presents the phylogenetic tree anaylsis.

In optimization of growth condition of RK33 isolate, it was found that while RK33 isolate was able to grow at 25 and $35^{\circ} \mathrm{C}, 30^{\circ} \mathrm{C}$ was the optimum temperature for its growth (Fig. 2). Furthermore, this isolate was able to grow in acidic, neutral and alkaline $\mathrm{pH}$, but maximum growth yield was obtained at neutral pH (Fig. 3).

Table 2. Biological activity of selected PSB strains. Ox, oxalic acid; Ci, citric acid; ND, not detected

\begin{tabular}{|c|c|c|c|c|c|}
\hline \multirow[t]{2}{*}{ Isolates } & \multicolumn{2}{|c|}{$\begin{array}{l}\text { Calcium phosphate solubilization } \\
\text { In broth assay }\end{array}$} & \multirow[t]{2}{*}{ Organic acid } & \multirow[t]{2}{*}{$\begin{array}{l}\text { Phytase activity } \\
\qquad\left(\mathrm{U} \mathbf{m L}^{-1}\right)\end{array}$} & \multirow[t]{2}{*}{$\begin{array}{l}\mathrm{N}_{2} \text { fixation } \\
\text { activity }\end{array}$} \\
\hline & $\mathbf{P}\left(\mathrm{mg} \mathrm{L}^{-1}\right)$ & $\mathrm{pH}$ & & & \\
\hline Control & 00.0 & $6.8-7.0$ & - & & \\
\hline RK24 & 12.84 & 5.9 & $\mathrm{Ox}$ & 0.261 & + \\
\hline RK25 & 26.20 & 5.3 & ND & - & + \\
\hline RK33 & 89.1 & 4.8 & $\mathrm{Ox}, \mathrm{Ci}$ & 0.876 & + \\
\hline RK21 & 6.74 & 6.4 & ND & - & + \\
\hline
\end{tabular}




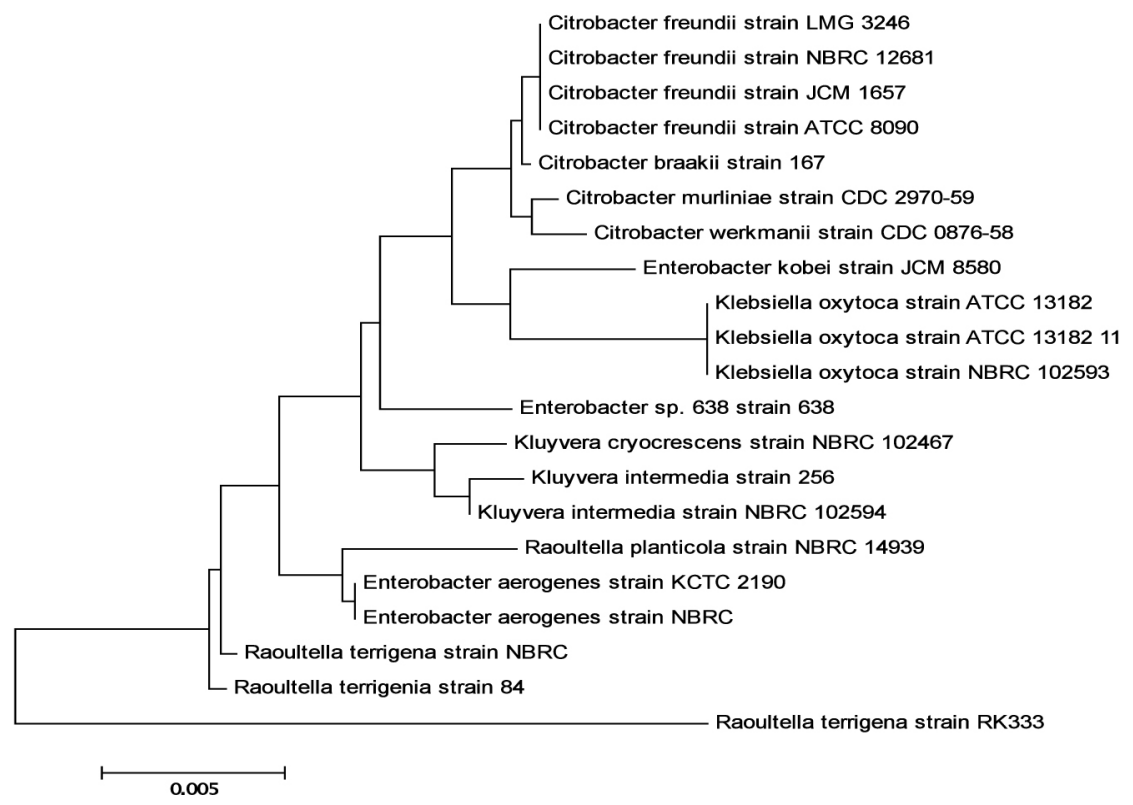

Fig. 1. Phylogenetic tree analysis based on $16 \mathrm{~S}$ rRNA sequence of RK33.

Effect of various parameters (temperature, $\mathrm{pH}$, various nitrogen sources and various carbon sources) on phosphate solubilizing activity of RK33 was studied. Optimized conditions for phosphate solubilization for by this isolate were $30^{\circ} \mathrm{C}, \mathrm{pH} 5.5$, glucose, yeast extract- $\left(\mathrm{NH}_{4}\right)_{2} \mathrm{SO}_{4}$ and 5 days incubation. The results are shown in Figs. 4, 5, 6, 7 and 8 .

\section{Discussion}

Several soil bacteria associated with plant rhizosphere, are useful for plants. Some of them have the ability to dissolve inorganic phosphate and hence have potential use as biofertilizers in agriculture. Phosphate solubilizing bacteria have different mechanisms of action and also wide diversity and can be used in management of sustainable agricultural systems (Zaidi et al. 2009) Application of phosphate solubilizing bacteria in promoting soil fertility (Shokri et al. 2012), enhancing biological nitrogen fixation (Mahantesh

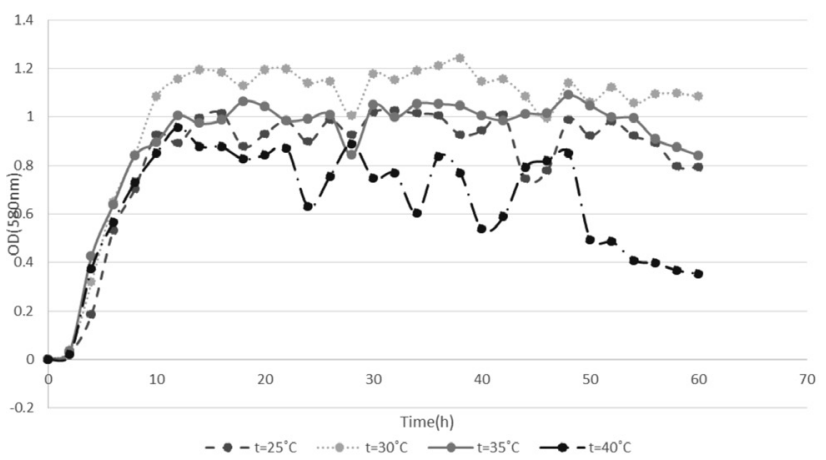

Fig. 2. Growth curve of RK33 strain at different temperatures. et al. 2011) and biological remediation of lead (Park et al. 2010) and cadmium (Jeong et al. 2012) polluted soil has been shown.

Apart from phosphate solubilizing abilities, some of these bacteria can have a direct consequence on plant growth by several different mechanisms, such as enhancing nitrogen fixation, production of phytohormones (indole3-acetic acid, gibberellin), production of phosphatase and phytase enzymes and enhancing the availability of other trace elements etc. (Gyaneshwar et al. 2002; Walpola, Yoon 2012; Karpagam, Nagalakshmi 2014). For example, in the study of Barea et al. (1976), 20 isolates of phosphatedissolving bacteria of tested 50 isolates synthesized three types of plant hormones, including indole-3-acetic acid, gibberellins and cytokinins, while 43 isolates produced only indole-3-acetic acid. Gibberellins were produced by 29 isolates and 45 of bacterial cultures produced cytokininlike substances (Barea et al. 1976). Thus, intensive screening of phosphate solubilizing bacteria with genetic potential for

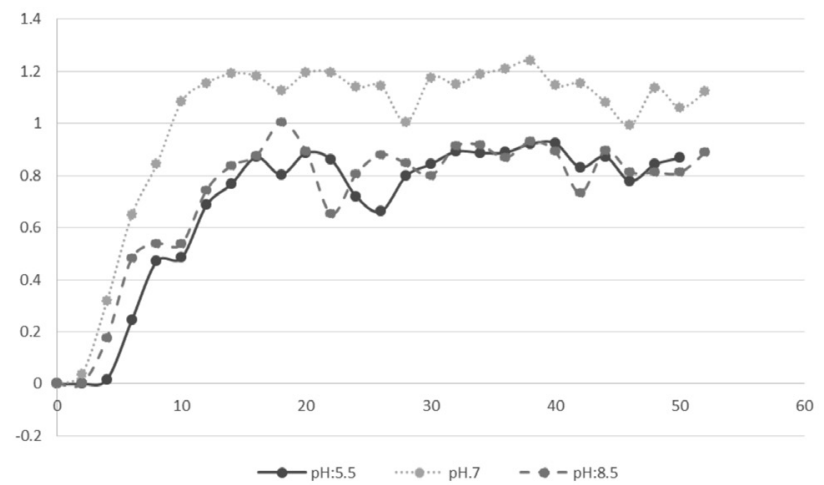

Fig. 3. Growth curve of RK33 strain at different $\mathrm{pH}$. 


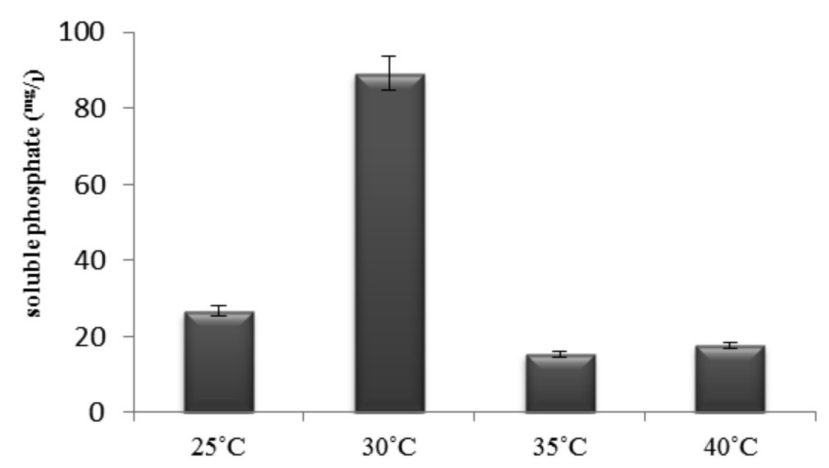

Fig. 4. Phosphate solubilization activity of RK33 at different temperatures.

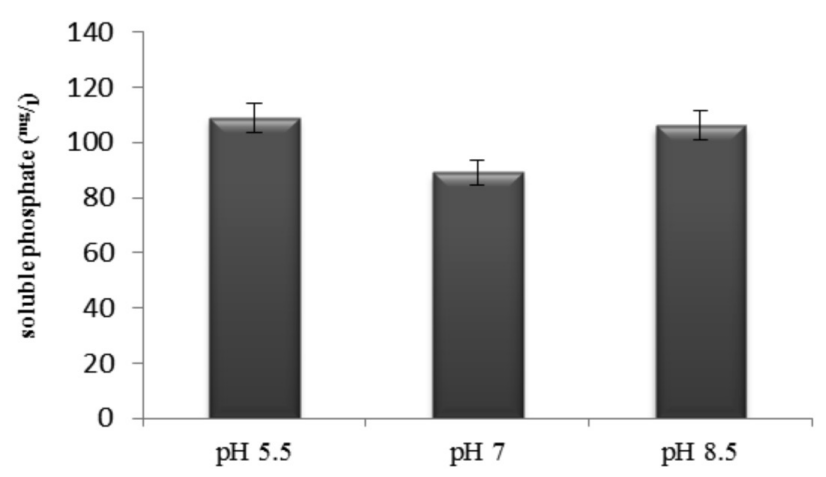

Fig. 5. Phosphate solubilization activity of RK33 at $30^{\circ} \mathrm{C}$ and different $\mathrm{pH}$.

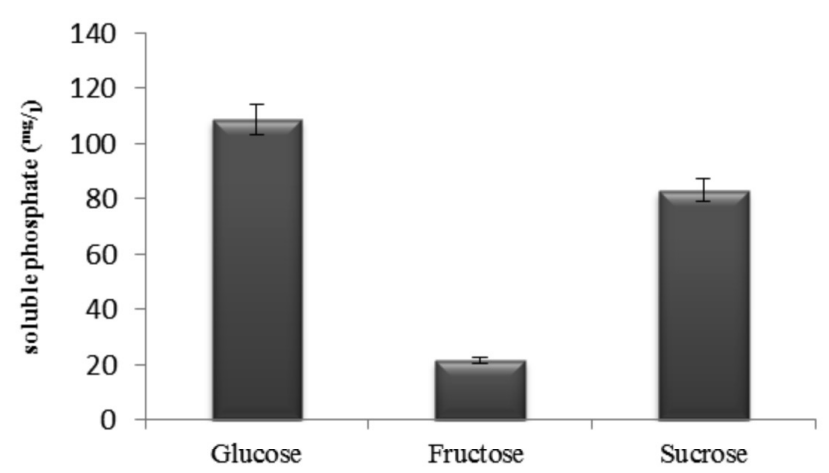

Fig. 6. Phosphate solubilization activity of RK33 at $30{ }^{\circ} \mathrm{C}, \mathrm{pH} 5.5$ and with different carbon sources

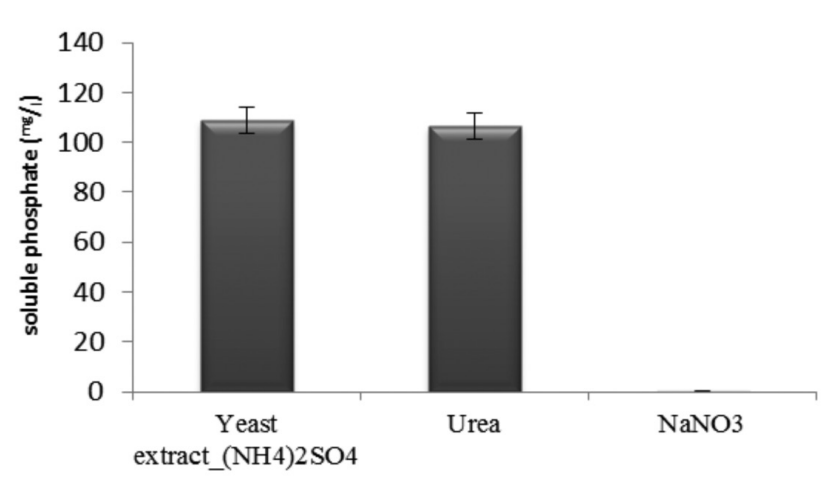

Fig. 7. Phosphate solubilization activity of RK33 at $30{ }^{\circ} \mathrm{C}, \mathrm{pH} 5.5$, glucose as carbon source and with different nitrogen sources. increased resistance to extreme salt, $\mathrm{pH}$ and temperature in arid and semi-arid area, can help to choose the best bacteria for use in production of biological fertilizers (Mehta et al. 2001; Ramani 2011). Several studies have reported the isolation of phosphate solubilizing bacteria from rhizospheric soil (Barea et al. 1976; Prasanna et al. 2011; Ghosh et al.2012; Ambrosini et al.2012). In the present study, cabbage rhizosphere was selected for isolation of phosphate solubilizing bacteria. This habitat was chosen due to greater possibility of occurrence of phosphate solubilizing bacteria. Panhwar et al. (2012) found considerably higher number of PSB population in the rhizosphere in comparison with non rhizospheric or bulk soil. Barea et al. (1976) also screened several rhizospheric bacteria for phosphate solubilizing potential.

PSB strains are commonly screened using Pikovskaya's agar, in which insoluble tricalcium phosphate is used as the sole source of phosphorus. The strains that can produce a clear zone around the colony are selected as having potent phosphate solubilizing ability (Chung et al. 2005). However, the reliability of this halo-based technique is questioned, as many strains that did not produce visible halo zone on agar plates could solubilize insoluble inorganic phosphate in liquid medium (Nautiyal 1999; Fernandez et al. 2007). For example, in this study, RK25 isolate did not produce clear halo zone on agar plates, but had higher phosphate solubilizing activity in the broth medium. Similar results were reported by Hui et al. (2011) and Hariprasad and Niranjana (2009). In this study, 14 bacterial isolates produced a halo zone around colonies; of these the four best isolates were selected based on the phosphate solubilizing index and efficiency. Results showed that among these four potent isolates, the RK24 strain was the most efficient phosphate solubilizer on PVK medium with SI 4.66 and PSE 366.6. These results are interesting in comparison with results found by Qureshi et al. (2012) and Ghosh et al. (2012). Modified Pikovskaya's agar containing bromophenol blue as indicator was used, which can improve the clarity and visibility of the yellow-colored halo around colonies. Yellow colored halos are observed around the colonies in response

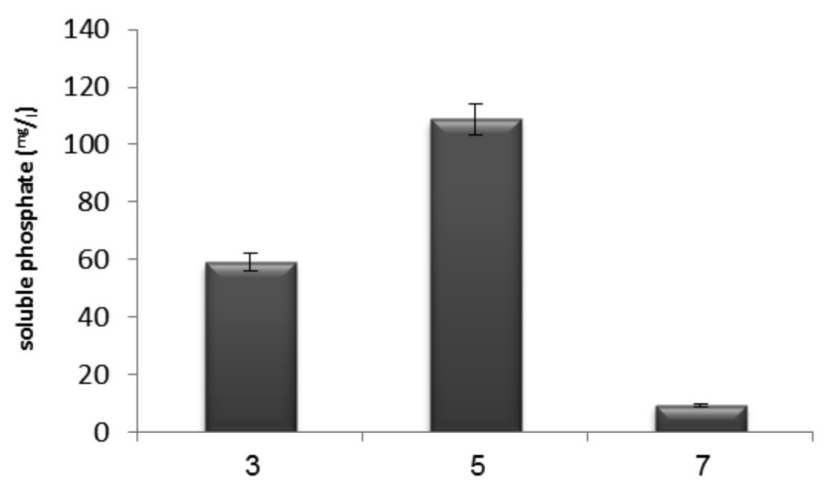

Fig. 8. Effect of incubation period on phosphate solubilization activity of $\mathrm{RK} 33\left(30{ }^{\circ} \mathrm{C}, \mathrm{pH} 5.5\right.$, glucose and yeast extract$\left.\left(\mathrm{NH}_{4}\right)_{2} \mathrm{SO}_{4}\right)$. 
to the $\mathrm{pH}$ reduction due to releasing organic acid. This result is in accordance with Nautiyal (1999); Rodriguez et al. (1999) and Mehta et al. (2001).

RK33, RK24, RK21 and RK25 strains were selected for quantitative assay in the PVK broth medium; of these RK33 had higher P solubilizing ability with $89.1 \mathrm{mg} \mathrm{L}^{-1}$. The phosphate solubilizing activity of the strains isolated from rhizosphere was examined by Chung et al. (2005), Prasanna et al. (2011) and Sarkaret al. (2012). In the present study, a linear relationship was observed between the $\mathrm{pH}$ and the released P by PSB strains (Table 2). This indicates that increase of released phosphorous in the broth medium (6.7 to $89.1 \mathrm{mg} \mathrm{L}^{-1}$ ) was parallel to a considerable reduction in $\mathrm{pH}$ (from $6.8-7.0$ to $4.8-6.4$ ) after 5 days. This was reported earlier by Chen et al. (2006), Sharma et al. (2011), Xiang et al. (2011) and Gosh et al. (2012). However, Tao et al. (2008) reported that there was no correlation between the $\mathrm{pH}$ of culture medium and the $\mathrm{P}$ mineralization by the organic phosphorus mineralizing bacteria, suggesting that mineralization of organic phosphorus may have different mechanisms of phosphorus solubilizing. Decrease of the $\mathrm{pH}$ owing to the production of organic acids like gluconic, fumaric, lactic, isovaleric, isobutyric, oxalic and citric acid was reported by several early researchers (Song et al. 2008; Ahmed, Shahab 2011; Walpola, Yoon 2012). Those bacteria that produced halo zones around colonies in PVK medium were able to produce organic acids in broth culture. This result is in accordance with Ogut et al. (2010). This is also in agreement with Mehta et al. (2001), Chen et al. (2006), Ivanova et al. (2006), Ponmurugan and Gopi (2012), and Karpagam and Nagalakshmi (2014) who recorded production of organic acids like butyric, malonic, succinic, malic, gluconic, acetic, glucenic, tartaric, gluconic, maleic, propionic, adipic and 2-ketogluconic acids by PSB in broth culture. Studies related to the production of organic acids have shown that citric and oxalic acids were two major organic acids produced by PSB (Alam et al. 2002). In this study, the presence of oxalic acid, citric acid, malic acid and tartaric acid was investigated in the supernatant using thin layer chromatography technique. Production of citric and oxalic acid by RK33 and RK24 strains was confirmed and estimated to be about $10 \mathrm{mg} \mathrm{mL}^{-1}$. Hariprasad and Niranjana (2009) examined organic acid production by phosphate solubilizing bacteria isolated using thin layer chromatography and reported variety of organic acids such as citric acid, oxalic acid, lactic acid and gluconic acid. Ogut et al. (2010) detected gluconic acid from Acinetobacter PSB strains. They reported that there was a linear regression between soluble $\mathrm{P}$ and gluconic acid concentration in the bacterial culture, and also that production of gluconic acid directly affected phosphate solubilization. Chen et al. (2006) reported production of citric acid, lactic acid, gluconic acid, succinic acid and propionic acid by PSB isolated from subtropical soil. Also, many of these isolates showed presence of multiple organic acids. Contradiction or similarities may be explained on the basis that type and quantity of produced acid depends on the PSB strain, media composition, growth conditions and several other factors (Alam et al. 2002).

In this study, the indigenous strains isolated from cabbage rhizosphere were able to produce phytase enzymes and fix nitrogen, which are known to have beneficial effects on $\mathrm{P}$ solubilization as well as promotion of plant growth (Ponmurugan, Gopi 2006). Production of phytase and $\mathrm{N}_{2}$ fixation ability of PSB was reported by Hariprasad et al. (2009) and Panhwar et al. (2012). For the RK33 isolate 30 ${ }^{\circ} \mathrm{C}$ temperature was the optimum temperature for growth and phosphate solubilization. The results showed that with increasing temperature, reduced solubilizing activity occur. Different temperatures have been reported by earlier workers for solubilization, most of them in the range 30 to $40{ }^{\circ} \mathrm{C}$ as optimum temperatures (Karpagam, Nagalakshmi 2014). Results showed that the RK33 isolate was able to solubilize $\mathrm{P}$ in the $\mathrm{pH}$ range from 5.5, 7 and 8.5. Maximum $\mathrm{P}$ solubilization and growth was recorded at $\mathrm{pH} 5.5$ and 7 , respectively. When various carbon sources were used, it was found that PVK with glucose followed by sucrose gave maximum $\mathrm{P}$ solubilization. Maheswar and Sathiyavani (2012) found that incorporation of glucose followed by lactose increased solubilization of phosphate. Examining the effect of various nitrogen sources on phosphate solubilization revealed that $\left(\mathrm{NH}_{4}\right)_{2} \mathrm{SO}_{4}$-yeast extract had maximum $\mathrm{P}$ solubilization followed by urea. $\mathrm{NaNO}_{3}$ addition resulted in much less $\mathrm{P}$ solubilization. Sagervanshi et al. (2012) revealed that $\left(\mathrm{NH}_{4}\right)_{2} \mathrm{SO}_{4}$ showed maximum $\mathrm{P}$ solubilization followed by casein. Urea and $\mathrm{NaNO}_{3}$ resulted in much less P solubilization.

Phosphate-solubilizing bacterial strains isolated were identified by biochemical tests; the strains RK21, RK24, RK25 and RK33 were identified as Aeromonas sp., Proteus sp., Proteus mirabilis and Raoultella terrigenia, respectively. Diversity of these bacterial genera showed that many bacteria have the phosphate-solubilizing ability and it is not exclusive to selective genera, suggesting the importance of preliminary screening for a wide range of bacteria to characterize their potential of phosphate-solubilizing activity (Gosh et al. 2012). Enterobacter sp., Burkholderia sp. and Bradyrhizobium sp. (Fernandez et al. 2007), Pseudomonas sp. (Poonguzhali et al. 2008), Bacillus sp. and Burkholderia sp. (Oliveira 2009), Micrococcus, Serratia, Bacillus and Klebsiella (Prasanna 2011), Pseudomonas, Serratia, Enterobacter and Rhizobium (Ambrosini 2012) and Bacillus sp. (Zhang 2012; Xiang 2011), have been reported as the potential PSB. As the RK33 strain showed the maximum phosphate solubilizing activity, it was subjected to molecular taxonomic studies for identification of this species. The 16S rRNA sequence of RK33 strain exhibited $98 \%$ similarity to Raoultella terrigena. To our knowledge, this is the first time that isolation of Raoultella terrigena from cabbage rhizosphere has been reported in 
Iran. Finally, based on these results it can be concluded that these isolates are potent phosphate solubilizing agents that can be applied as bio-fertilizer in agriculture and also for industrial purposes such as extracting phosphorus from phosphate rock.

\section{Acknowledgements}

The authors wish to thank vice chancellor of research of Shahid Chamran University of Ahvaz for providing research grant (Grant No. 874095) and also MSc. thesis grant.

\section{References}

Ahmed N., Shahab S. 2011. Phosphate solubilization: Their mechanism genetics and application. Int. J. Microbiol. 9: 44084412.

Alam S., Khalil S., Ayub N., Rashid M. 2002. In vitro solubilization of inorganic phosphate by phosphate solubilizing microorganisms (PSM) from maize. Int. J. Agric. Biol. 4: 454458.

Ambrosini A., Beneduzi A., Stefanski T., Pinheiro F.G., Passaglia L.M.P. 2012. Screening of plant growth promoting Rhizobacteria isolated from sunflower (Helianthus annuus L.). Plant Soil 356: 245-264.

Antoun H. 2012. Beneficial microorganisms for the sustainable use of phosphates in agriculture. Procedia Eng. 46: 62-67.

Barea JM., Navarro E., Montoya E. 1976. Production of plant growth regulators by rhizosphere phosphate solubilizing bacteria. J. Appl. Microbiol. 40: 129-134.

Chen Y.P., Rekha P.D., Arun A.B., Shen F.T., Lai W.A., Young C.C. 2006. Phosphate solubilizing bacteria from subtropical soil and their tricalcium phosphate solubilizing abilities. Appl. Soil Ecol. 34: 33-41.

Chung H., Park M., Madhaiyan M., Seshadri S., Song J., Cho H., Sa T. 2005. Isolation and characterization of phosphate solubilizing bacteria from the rhizosphere of crop plants of Korea. Soil Biol. Biochem. 37: 1970-1974.

Dobereiner J., Day J.M., Dart P.J. 1972. Nitrogenase activity and oxygen sensitivity of the Paspalum notatum-Azotobacter paspali association. J. Gen. Microbiol. 71: 103-116.

Fernandez L.A., Zalba P., Gómez M.A., Sagardoy M.A. 2007. Phosphate-solubilization activity of bacterial strains in soil and their effect on soybean growth under greenhouse conditions. Biol. Fertil. Soils 43: 805-809.

Ghosh U., Subhashini P., Dilipan E., Raja S., Thangaradjou T., Kannan L. 2012. Isolation and characterization of phosphatesolubilizing bacteria from sea grass rhizosphere soil. J. Ocean Univ. China 11: 86-92.

Guinazu L.B., Andres J.A., Del Papa M.F., Pistorio M., Rosas S.B. 2010. Response of alfalfa (Medicago sativa L.) to single and mixed inoculation with phosphate-solubilizing bacteria and Sinorhizobium meliloti. Biol. Fertil. Soils 46:185-190.

Gyaneshwar P., Kumar G.N., Parekh L.J., Poole P.S. 2002. Role of soil microorganisms in improving $\mathrm{P}$ nutrition of plants. Plant Soil 245: 83-93.

Hariprasad P., Niranjana S.R. 2009. Isolation and characterization of phosphate solubilizing rhizobacteria to improve plant health of tomato. Plant Soil 316: 13-24.

Hui L., Xiao-Qin W., Jia-Hong R., Jian-Ren Y. 2011. Isolation and identification of phosphobacteria in poplar rhizosphere from different regions of China. Pedosphere 21: 90-97.

Ivanova R., Bojinova D., Nedialkova K. 2006. Rock phosphate solubilization by soil bacteria. J. Univ. Chem. Technol. Metallur. 41: 297-302.

Jeong S., Moon H.S., Nam K., Kim J.Y., Kim T.S. 2012.Application of phosphate-solubilizing bacteria for enhancing bioavailability and phytoextraction of cadmium (Cd) from polluted soil. Chemosphere 88: 204-210.

Karpagam T.,Nagalakshmi P.K.2014.Isolation and characterization of phosphate solubilizing microbes from agricultural soil. Int. J. Curr. Microbiol. Appl. Sci. 3: 601-614.

Khan A.A., Jilani G., Akhtar M.S., Naqvi S.S., Rasheed M. 2009. Phosphorus solubilizing bacteria: occurrence, mechanisms and their role in crop production. J. Agric. Biol. Sci. 1: 48-58.

Kundu B.S., Nehra K., Yadav R., Tomar M. 2009. Biodiversity of phosphate solubilizing bacteria in rhizosphere of chickpea, mustard and wheat grown in different regions of Haryana. Indian J. Microbiol. 49: 120-127.

Mahantesh P., Patil C.S. 2011. Isolation and biochemical characterization of phosphate solubilizing microbes. Int. J. Microbiol. Res. 3: 67-70.

Mehta S., Nautiyal C.S. 2001. An efficient method for qualitative screening of phosphate-solubilizing bacteria. Curr. Microbiol. 43: 51-56.

Mittal A., Singh G., Goyal V., Yadav A., Aneja K.R., Gautam S.K., Aggarwal N.K. 2011. Isolation and biochemical characterization of acido-thermophilic extracellular phytase producing bacterial strain for potential application in poultry feed. Jundishapur J. Microbiol. 4: 273-282.

Nautiyal C.S. 1999. An efficient microbiological growth medium for screening phosphate solubilizing microorganisms. FEMS Microbiol. Lett. 170: 265-270.

Ogut M., Er F., Kandemir N. 2010. Phosphate solubilization potentials of soil Acinetobacter strains. Biol. Fertil. Soils 46: 707-715.

Oliveira C.A., Alves V.M.C., Marriel I.E., Gomes E.A., Scotti M.R., Carneiro N.P., Guimaraes C.T., Schaffert R.E., Sa N.M.H. 2009. Phosphate solubilizing microorganisms isolated from rhizosphere of maize cultivated in an oxisol of the Brazilian Cerrado Biome. Soil Biol. Biochem. 41: 1782-1787.

Panhwar Q.A., Othman R., Abdul Rahman Z., Meon S., Ismail M. 2011. Isolation and characterization of phosphate solubilizing bacteria from aerobic rice. Afr. J. Biotechnol. 11: 2711-2719.

27- Park J., Bolan N., Megharaj M., Naidu R. 2011. Isolation of phosphate-solubilizing bacteria and characterization of their potential for lead immobilization in soil. J. Hazard. Mater. 185: 829-836.

Ponmurugan P., Gopi C. 2006. In vitro production of growth regulators and phosphatase activity by phosphate solubilizing bacteria. Afr. J. Biotechnol. 5: 348-350.

Poonguzhali S., Madhaiyan M., Sa T. 2008. Isolation and identification of phosphate solubilizing bacteria from Chinese cabbage and their effect on growth and phosphorus utilization of plants. J. Microbiol. Biotechnol. 18: 773-777.

Popanich S., Klomsiri C., Dharmsthiti S. 2003. Thermo-acidotolerant phytase production from a soil bacterium in a medium containing rice bran and soybean meal extract. Bioresour. Technol. 87: 295-298.

Prasanna A., Deepa V., Balakrishna Murthy P., Deecaraman M., Sridhar R., Dhandapani P. 2011. Insoluble phosphate solubilization by bacterial strains isolated from rice rhizosphere soils from Southern India. Int. J. Soil Sci. 61: 34- 
14

Prescott H. 2002. Laboratory Excercises in Microbiology. $5^{\text {th }}$ Ed.. McGraw Hill, New York.

Qureshi M.A., Ahmad Z.A., Akhtar N., Iqbal A., Mujeeb F., Shakir M.A. 2012. Role of phosphate solubilizing bacteria (PSB) in enhancing $\mathrm{p}$ availability and promoting cotton growth. J. Anim. Plant Sci. 22: 204-210.

Ramani V.2011. Effect of pesticides on phosphate solubilization by Bacillus sphaericus and Pseudomonas cepacia. Pest. Biochem. Physiol. 99: 232-236.

Rodriguez H., Fraga R. 1999. Phosphate solubilizing bacteria and their role in plant growth promotion. Biotechnol. Adv. 17: 319-339.

Sarkar A., Islam T., Biswas G.C., Alam S., Hossain M., Talukder N.M. 2012. Screening for phosphate solubilizing bacteria inhabiting the rhizoplane of rice grown in acidic soil in Bangladesh. Acta Microbiol. Immunol. Hung. 59: 199-213.

Savci S. 2012. Investigation of effect of chemical fertilizers on environment. APCBEE Procedia 1: 287-292.

3Sgroy V., Cassan F., Masciarelli O., Del Papa M.F., Lagares A., Luna V. 2009. Isolation and characterization of endophytic plant growth-promoting (PGPB) or stress homeostasis-regulating (PSHB) bacteria associated to the halophyte Prosopis strombulifera. Appl. Microbiol. Biotechnol. 58: 371-381.

Sharma A.K. 2002. Biofertilizers for sustainable agriculture. Agrobios 12: 319-324.

Shokri H., Shahinrokhsar P., Heydarnezhad F. 2012. Performance of phosphate solubilizing bacteria for improving growth and yield of rice (Oryza sativa L.) in the presence of phosphorus fertilizer. Int. J. Agric. Crop Sci. 4: 1228-1232.

Song O.R., Lee S.J., Lee Y.S., Lee S.C., Kim K.K., Choi Y.L. 2008. Solubilization of insoluble inorganic phosphate by Burkholderia cepacia DA23 isolated from cultivated soil. Braz.
J. Microbiol. 39: 151-156.

Tao G.C., Tian S.J., Cai M.Y., Xie G.H. 2008. Phosphate-solubilizing and -mineralizing abilities of bacteria isolated from soils. Pedosphere 18: 515-523.

Vessey J.K. 2003. Plant growth promoting rhizobacteria as biofertilizers. Plant Soil 255: 571-586.

Walpola B.C., Yoon M. 2012. Prospectus of phosphate solubilizing microorganisms and phosphorus availability in agricultural soils. Afr. J Microbiol. Res. 6: 6600-6605.

Watanabe F.S., Olsen A.S. 1965. Test of an ascorbic acid method for determining phosphorus in water and $\mathrm{NaHCO}_{3}$ extracts from soil. Soil Sci. Soc. Am. J. 29: 677-678.

Weisburg W.G., Barns S.M., Pelletier D.A., Lane D.J. 1991. 16S ribosomal DNA amplification for phylogenetic study. J. Bacteriol. 173: 697-703.

Xiang W.L., Liang H.Z., Liu S., Luo F., Tang J., Li M.Y., Che Z.M. 2011. Isolation and performance evaluation of halotolerant phosphate solubilizing bacteria from the rhizospheric soils of historic Dagong Brine Well in China. World J. Microbiol. Biotechnol. 27: 2629-2637.

Yadav B.K., Verma A. 2012. Phosphate solubilization and mobilization in soil through microorganisms under arid ecosystems. In: Ali M. (ed) The Functioning of Ecosystems. Intec Press, India, pp. 99-108.

Zaidi M., Khan M., Ahmed M., Oves M. 2009. Plant growth promotion by phosphate solublizing bacteria. Acta Microbiol. Immunol. Hung. 56: 263-284.

Zhang J., Liu J., Meng L., Ma Z., Tang X., Cao Y., Sun L. 2012. Isolation and characterization of plant growth-promoting rhizobacteria from wheat roots by wheat germ agglutinin labeled with fluorescein isothiocyanate. J. Microbiol. 50: 191198. 